\title{
PENGEMBANGAN MEDIA PROMOSI BOOKLET SEBAGAI SARANA PROMOSI KEDAI NYOSOE CAK NANANG DI DESA KEMUNING LOR KABUPATEN JEMBER
}

\author{
Titik Ismailia1), Alfi Hidayatu Miqawati'1), Fitri Wijayanti'1), Septian Hadi Sasmita1), Ulfa Denadia1) \\ 1)Program Studi Bahasa Inggris, Jurusan Bahasa, Komunikasi dan Pariwisata, Politeknik Negeri Jember, Jember, Jawa \\ Timur, Indonesia \\ Corresponding author : Alfi Hidayatu Miqawati \\ E-mail : alfi_hidayatu@polije.ac.id
}

Diterima 30 November 2021, Direvisi 04 Desember 2021, Disetujui 05 Desember 2021

\begin{abstract}
ABSTRAK
Pengabdian kepada masyarakat merupakan salah satu Tridharma perguruan tinggi yang wajib dilakukan oleh dosen. Kegiatan Pengabdian kepada Masyarakat (PkM) ini dilaksanakan di salah satu UMKM, Kedai Nyosoe Cak Nanang, yang terletak di Desa Kemuning Lor Jember. Kedai ini memiliki produk andalan susu murni segar dan olahannya seperti susu rasa-rasa, milkshake, dan yogurt Letak kedai ini sangat strategis karena berada di wilayah rekreasi Rembangan. Namun, masih banyak masyarakat yang belum mengetahui produk kedai tersebut karena minimnya media promosi dan pengelola memiliki pengetahuan terbatas terkait promosi produk. Tujuan dari kegiatan PkM ini adalah untuk memberikan sosialisasi tentang media promosi dan mengembangkan booklet sebagai media promosi Kedai Nyosose Cak Nanang. Metode yang dilakukan untuk mengatasi masalah adalah sosialisasi dan penyusunan media promosi untuk kedai tersebut. Berdasarkan hasil yang dilakukan selama pelaksanaan pengabdian diperoleh hasil yaitu satu produk booklet bilingual dengan informasi lokasi kedai, produk susu beserta foto, dan nomor narahubung serta meningkatnya pemahaman pengelola tentang pentingnya promosi menggunakan booklet bilingual untuk meningkatkan omset penjualan.
\end{abstract}

Kata kunci: media promosi; booklet; produk susu.

\begin{abstract}
Community service is one of the Tridharma of higher education that must be carried out by lecturers. This Community Service (PkM) activity was carried out in Kedai Nyosoe Cak Nanang, which is located in Kemuning Lor Village, Jember. This shop has main products of fresh milk and its processed products such as flavored milk, milkshakes, and yogurt. Its location is very strategic because it is located in the Rembangan recreation area. However, there are still many people who do not know about its products because of the lack of promotional media and the owners have limited knowledge about product promotion. The purpose of this activity was to socialize about promotional media and develop a booklet as a medium of promotion for Kedai Nyosoe Cak Nanang. The method used to overcome the problem is socialization and making promotional media for the shop. Based on the results carried out during the implementation of the service, the results obtained were one bilingual booklet product completed with information about the location of the shop, dairy products along with photos, and contact numbers as well as the staffs' understanding about the importance of promotion using bilingual booklets to increase sales.
\end{abstract}

Keywords: promotional media; booklet; dairy products.

\section{PENDAHULUAN}

Desa Kemuning Lor Kecamatan Arjasa Jember terkenal dengan potensi wisata alam seperti puncak Rembangan, kebun bunga potong dan buah naga, air terjun, serta peternakan sapi perah. Desa inimerupakan salah satu desa wisata di Kabupaten Jember yang berbasis agro wisata, berbeda dengan desa wisata lainnya seperti Desa Sumbersalak yang berbasis alam (Ismailia et al., 2019).
Peternakan sapi perah dikelola oleh dinas peternakan Jember dan peternakan mandiri milik peternak pribadi. Dari peternakan tersebut, dihasilkan susu sapi segar yang kemudian diolah untuk memenuhi kebutuhan masyarakat sekitar.

Susu adalah produk bahan pangan yang berasal dari hewan mamalia seperti sapi, kambing, dan kerbau. Susu memiliki kandungan gizi yang lengkap dan dapat dikonsumsi oleh 
semua kalangan masyarakat mulai dari balita hingga lansia. Tentunya susu yang dikonsumsi memiliki kekhususan sesuai denga usia yang mengkonsumsinya. Selain itu susu sapi merupakan bahan pangan dengan gizi lengkap meliputi protein, lemak, karbohidrat, vitamin dan mineral. Susu mengandung kadar lemak 3,45\%, protein 3, 20\%, laktosa 4,60\%. Selanjutnya kualitas susu sapi ditentukan oleh komponen penyusun susu yang terdiri dari kadar lemak, protein, laktosa, vitamin, dan mineral atau disebut total solid (Nugraha et al., 2016).

Sebagai bahan pangan bermutu tinggi, pemasaran produk susu dilakukan tidak hanya sebagai susu segar murni tetapi juga olahan produk susu untuk menambah nilai jual. Salah satunya yaitu pemanfaatan susu dan buah naga merah menjadi yogurt (Aulia et al., 2021). Selain itu, susu dapat diolah menjadi susu pasteurisasi yang merupakan proses pengolahan susu dengan tujuan memperoleh susu yang beraneka ragam, berkualitas tinggi, berkadar gizi tinggi, tahan simpan, mempermudah pemasaran, dan transportasi (Yunita et al., 2019).

Produk susu perah di wilayah Rembangan dipasarkan di wilayah Jember dan sekitarnya karena keterbatasan penjual dan produk susu yang ada belum dapat memenuhi kebutuhan pelanggan. Produk susu yang dipasarkan diantaranya susu segar murni, susu rasa-rasa, milkshake, yogurt. Untuk dapat memasarkan produk diperlukan strategi pemasaran sesuai dengan barang atau jasa ynag akan dijual. Strategi pemasaran menjadi salah satu upaya dalam meningkatkan nilai atau angka penjualan suatu produk barang atau jasa. Strategi pemasaran merupakan usaha atau upaya untuk memasarkan produk barang atau jasa menggunakan pola rencana dan taktik tertentu sehingga penjualan dapat meningkat [Syahputra].

Strategi pemasaran meliputi 4P (product, price, place, promotion). Promosi menjadi salah satu cara dalam memasarkan produk susu di Rembangan Jember. Salah satu kedai yang menjual produk olahan susu yaitu Kedai Nyoesoe Cak Nanang yang berada di Desa kemuning Lor Jember. Kedai ini melakukan promosi dengan menjual langsung produk di kedai dan melalui media sosial Facebook dan Instagram. Pembeli dapat menghubungi nomor kontak yang tertera serta mendapatkan produk olahan susu yang diantar langsung ke rumah pembeli.

Promosi produk secara langsung memberikan keuntungan yaitu pembeli dapat merasakan secara langsung produk yang dijual serta dapat menanyakan secara langsung kualitas produk. Strategi ini juga memiliki kekurangan yaitu tidak dapat menjangkau wilayah yang lebih luas karena keterbatasan transportasi dan barang atau jasa yang dibawa. Strategi promosi lainnya yaitu melalui media sosial yang dapat menjangkau kalangan tua dan muda serta tidak terbatas wilayah. Jenis-jenis strategi promosi tersebut membutuhkan alat promosi media cetak seperti brosur, booklet, poster, banner, buku, majalah, koran.

Booklet sebagai salah satu media cetak memiliki keunggulan dapat menjangkau wilayah yang lebih luas karena dapat dibawa kemana saja karena ukurannya yang kecil. Booklet juga dapat digunakan sebagai pemberi informasi yang lengkap serta berisi teks atau tulisan dan gambar atau foto berwarna yang lebih menarik (Nikmah Rahmatih et al., 2018). Berdasarkan informasi dari pengelola, Kedai Nyoesoe Cak Nanang belum memiliki media promosi berbentuk cetak. Pengelola juga belum memperbarui informasi pada akun Facebook atau Instagram dengan informasi mengenai produk yang dijual. Pembeli mengetahui produk setelah menghubungi nomor kontak pengelola dengan menanyakan secara langsung. Masalah selanjutnya yaitu minimnya jangkauan wilayah pemasaran karena keterbatasan loper susu dan jumlah susu yang dapat dipasarkan. Dengan demikian terdapat 2 permasalahan yang perlu diselesaikan sehingga tim pengabdian membantu dalam menangani masalah pertama yaitu pendampingan pembuatan booklet sebagai sarana promosi kedai. Tujuan dari kegiatan PkM ini adalah memberikan sosialisasi kepada mitra tentang media promosi dan mengenbangakan booklet untuk mitra sebagai media promosi pemasaran produknya dalam dua bahasa, bahasa Indonesia dan bahasa Inggris.

\section{METODE}

Metode pada pengabdian meliputi sosialisasi dan pengembangan media promosi. Mitra dari kegiatan ini adalah manajemen dan staf Kedai Nyosoe Cak Nanang yang berjumlah 10 orang. Kegiatan pertama yang dilakuakn adalah sosialisasi tentang media promosi. Kegiatan ini dilakukan sebanyak 2 pertemuan pada bulan Agustus 2021 di Kedai Nyosoe Cak Nanang. Pada kegiatan sosialisasi ini, tim memberikan sosialisasi terkait pentingnya manfaat media promosi dan identifikasi media promosi yang efektif digunakan saat. ini.

Kegiatan yang kedua adalah pembuatan media promosi yang terdiri dari beberap tahapan, yakni analisis media yang dibutuhkan, desain produk, try-out, revisi, finalisasi produk, pendampingan mitra dalam menggunakan media promosi, dan evaluasi 
proses dan hasil pengabdian. Kegiatan ini berlangsung selama 4 bulan dari bulan Agustus sampai bulan November 2021.

\section{HASIL DAN PEMBAHASAN}

Hasil dan luaran yang dicapai meliputi hasil sosilisasi dan pembuatan booklet. Pertama, tim pelaksana PkM mengadakan sosialisasi tentang peran media promosi dilakukan pada tanggal 6 Juli 2021 dengan mengadakan pertemuan langsung dengan pengelola, dan karyawan. Sosialisasi meliputi kunjungan ke kedai dan diskusi terfokus mengenai peran media promosi sebagai sarana mengembangkan usaha. Pengelola memberikan informasi bahwa belum pernah mendapatkan informasi mengenai pentingnya peran media promosi dalam usaha yang ditekuninya selama ini. Selama ini, pengelola belajar secara otodidak dalam mempromosikan usaha yang dijalannya selama 4 tahun sebagai loper susu yang menyediakan berbagai olahan susu baik dikedai maupun melalui pesan antar. Pengelola juga belum pernah mengikuti atau mendapatkan pelatihan mengenai bidang usahanya. Pengelola mengetahui selera masyarakat dari pengunjung yang datang ke kedai secara langsung maupun dari pelanggan setia susu murni di kota Jember. Pengelola dan karyawan merasa senang mendapatkan sosialisasi pentingnya penggunaan media dalam memberikan informasi kepada masyarakat tentang susu Rembangan terutama produk olahan susu di kedai yang dikelolanya.

Kedua, tim membuat media promosi yang tahapannya terdiri dari analisis media yang dibutuhkan, desain produk, try-out, revisi, finalisasi produk, pendampingan mitra dalam menggunakan media promosi. (Ismaillia et al., 2021) menyampaiakn bahwa berdasarkan hasil analisis kebutuhan, Kedai Nyoseo perlu memiliki media promosi langsung seperti brosur, leaflet, maupun booklet yang dapat digunakan untuk menambah informasi agar lebih jelas. Selain itu, pada tahap analisis, tim mengidentifikasi media promosi yang sudah ada menelusuri media sosial milik kedai Nyosoe Cak Nanang seperti Instagram, Facebook, dan Youtube dan mendatangi lokasi untuk melihat secara langsung media promosi yang dimiliki. Pada tahap ini tim dan pengelola melaukan diskusi dengan menyusun konsep booklet secara bersama-sama untuk menyamakan persepsi mengenai desain booklet dan isi booklet.

Selanjutnya dalam desain produk terdapat 4 kegiatan yaitu: penyusunan skrip, penerjemahan skrip dari Bahasa Indonesia ke
Bahasa Inggris oleh tim, pengambilan data-data booklet, dan pemilihan template. Pengumpulan data booklet dilakukan pada tanggal 22-23 Juli 2021 untuk mendapatkan informasi mengenai sejarah berdirinya kedai, proses pengolahan minuman susu rasa-rasa, dan foto lokasi. Tim beserta mahasiswa menanyakan berbagai hal yang berkaitan dengan penyusunan skrip booklet. Pengelola dan karyawan juga memberikan informasi yang lengkap sehingga tim mendapatkan gambaran tentang desain dan isi booklet yang sesuai. Berikutnya, penyusunan skrip dilakukan bersama dengan mitra pada tanggal 27 - 29 Juli 2021. Berdasarkan hasil pengumpulan data diperoleh informasi yang lengkap tentang kedai sehingga tim dan pengelola sepakat dengan desain booklet yang terdiri dari cover, prakata, sejarah, isi booklet, produk susu, proses pembuatan produk susu, testimoni, dan kontak dan lokasi. Cover berisi foto Rembangan, peternakan susu, tampak depan kedai dengan logo tulisan dan logo kedai. Prakata berisi tentang uraian memperkenalkan Rembangan sebagai tempat wisata. Sejarah berisikan asal mula dan waktu kedai beroperasi dan produk yang dipasarkan pertama kali. Produk susu berisikan macammacam olah susu yang dijual oleh kedai. Proses pengolahan susu berisi tentang prosen pembuatan olahan susu segar siap minum, susu rasa-rasa, yogurt, dan milkshake. Desain model booklet sederhana dan mudah di mengerti bahasanya dalam Bahasa Indonesia dan Bahasa Inggris. Warna dasar booklet yaitu emas, hitam, putih, dan coklat yang sesuai dengan tema mural dinding kedai yaitu hitam, putih, dan coklat. Informasi yang disampaikan dalam booklet yaitu: jenis produk olahan susu yang di pasarkan, dan proses pengolahan minuman susu. Foto yang disajikan meliputi tampak luar kedai, produk olahan susu, cara pembuatan olahan susu, serta logo yang yang dapat menarik minat konsumen untuk membeli produk olahan susu tersebut. Nomor kontak yang dapat dihubungi sebagai sarana pemesanan produk, lokasi kedai dengan barcode, dan slogan ajakan minum susu segar setiap hari.

Tahap selanjutnya adalah penerjemahan skrip yang dilakukan oleh tim selama 3 hari yaitu pada tanggal 30,31 Juli dan 1 Agustus 2021. Penerjemahan bertujuan untuk memberikan informasi dalam dua bahasa agar pengelola dan Rembangan dapat menarik minat turis asing dari luar negeri untuk dapat berkunjung dan memperoleh informasi yang lengkap mengenai produk kedai Nyoesoe. Booklet ini selain berbentuk cetak juga dapat diunggah pada media sosial milik kedai untuk 
menambah kelengkapan informasi yang telah ada. Terakhir, pada pemilihan template, tim dan pengelola melakukan proses editing pada tanggal 12 dan 13 Agustus 2021. Berdasarkan desain yang telah didiskusikan pada tahap sebelumnya, serta skrip yang telah disusun terbentuklah satu draf booklet sesuai dengan rancangan.

Tahap try-out dilakukan pada tanggal 7 dan 8 September 2021 dengan memberikan booklet yang sudah dicetak kepada pelanggan dan calon pembeli produk olahan susu di kedai Nyoesoe Cak Nanang. Try-out bertujuan untuk mendapatkan masukan tentang disain booklet, dan informasi yang disampaikan. Selain itu juga untuk semakin memberikan keyakinan bahwa produk susu yang dikonsumsi berkualitas dan diproses secara higienis. Tim beserta mahasiswa,dan pengelola kedai ikut serta mengujicobakan booklet kepada kolega dan pelanggan untuk mendapatkan masukan terkait tata letak, kelengkapan informasi, dan bahasa yang digunakan. Berdasarkan hasil try-out, pengelola memberikan masukan:pertama, foto pada sampul muka diganti dengan foto kedai Nyoesoe dan bukan foto peternakan sapi perah karena menganggap bahwa peternakan tersebut bukan milik pengelola kedai. Kedua, foto dan informasi tentang makanan ringan ditambah dengan beberapa menu yang dapat dipesan langasung dikedai seperti roti bakar, roti maryam, dan mie instan. Sedangkan masukan dari pelanggan kedai mengatakan bahwa booklet sudah bagus dan informasi yang disampaikan cukup jelas serta membantu pelanggan mengenal produk kedai Nyoesoe Cak Nanang secara lebih detail. Selanjutnya, berdasarkan masukan tersebut akan dilakukan revisi baik terhadap disainnya maupun informasi serta foto dan gambar yang disajikan.

Tahap revisi dilakukan berdasarkan masukan yang diperoleh yaitu pada perubahan foto dan informasi pada booklet yaitu pada halaman sampul muka dan hal 8 tentang informasi dan foto aneka makanan ringan. Selanjutnya tim juga memberikan masukan tentang logo yang digunakan yaitu logo kementerian, logo Polije, dan logo komersial Polije, serta nama anggota tim pengabdian dan gambar background gedung polije.
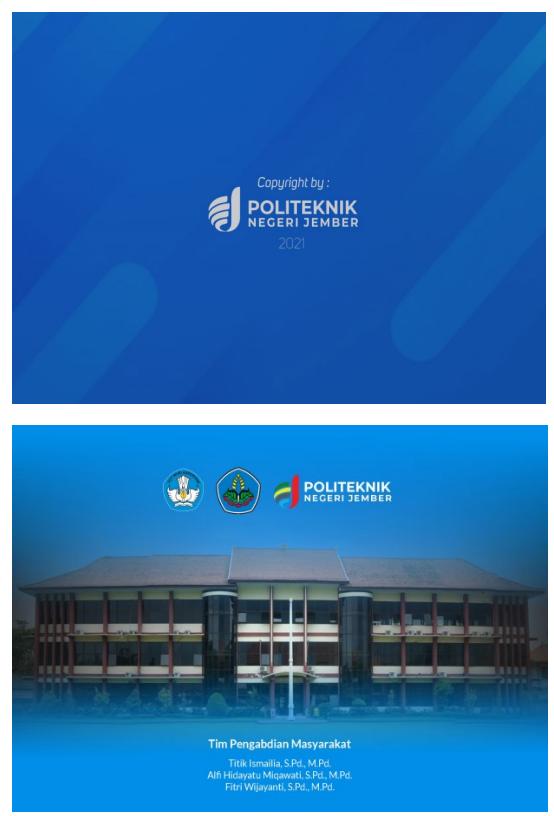

Gambar 1. Logo belakang booklet

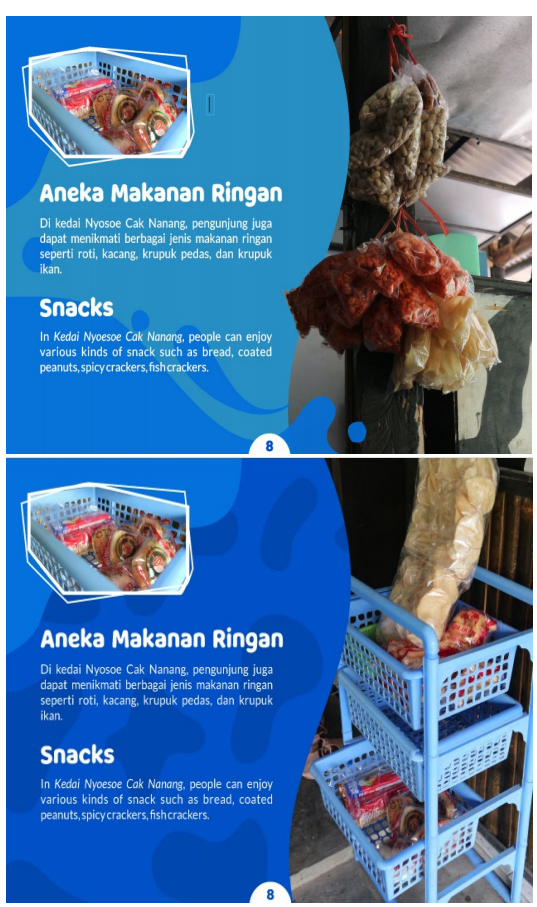

Gambar 2. Sampel isi booklet

Tahap finalisasi produk dilakukan dengan mencetak menggunakan kertas foto berukuran A5 keseluruhan isi booklet bilingual sebanyak 10 eksemplar dan menyerahkan kepada pengelola kedai Nyoesoe Cak Nanang. Selain itu tim juga menyerahkan softfile booklet bilingual kepada pengelola jika ingin mengunggah pada laman Facebook atau Instagram.

Ketiga, tahap pendampingan mitra dalam menggunakan booklet dilakukan dengan bagaimana memanfaatkan printed dan electronik booklet untuk meningkatkan promosi. Pendampingan dilakukan dengan 
memanfaaatkan printed booklet untuk diberikan kepada pelanggan yang membutuhkan informasi mengenai produk susu yang dijual oleh kedai. Printed booklet juga dapat diberikan kepada pelanggan mancanegara yang singgah dikedai jika ada karena informasi yang diberikan menggunakan dua bahasa yaitu Indonesia dan Inggris. Akan tetapi selama proses pendampingan belum ada pelanggan dari mancanegara yang datang ke kedai karena ada larangan kunjungan dari luar negeri efek dari pandemi Covid-19. Sedangkan elektronic booklet dapat diunggah pada akun Facebook dan Instagram.

Keempat, evaluasi yang telah dilakukan terdiri dari dua jenis, evaluasi proses dan evaluasi hasil. Evaluasi proses yang telah dilakukan selama proses pendampingan pembuatan media promosi dwibahasa sebagai berikut: pertama, pengelola dan karyawan melaksanakan keseluruhan proses mulai dari identifikasi proses pembuatan produk, membuat deskripsi masing-masing produk, menyeleksi foto, dan membuat disain booklet. Selanjutnya, disain booklet diberikan kepada editor untuk divisualkan menjadi hasil keseluruhan booklet. Tim membantu dalam proses penerjemahan dari bahasa Indonesia ke bahasa Inggris. Booklet yang sudah jadi kemudian diujicobakan kepada pelanggan kedai. Berdasarkan komentar pelanggan, tim melakukan revisi dan finalisasi booklet. Kedua, tim juga melaksanakan pendampingan dalam menggunakan booklet versi cetak dan elektronik kepada pengelola dan karyawan kedai. Selanjutnya evaluasi hasil dilakukan dengan menganalisis efektivitas media promosi yang telah dibuat. Berdasarakan hasil uji coba kepada pelanggan kedai, tm pendapatkan informasi bahwa booklet ini telah membantu pelanggan mengetahui informasi kedai dan produknya secara lebih mendalam. Selain itu, disain booklet juga menarik dan diharapkan pelanggan dapat memberikan informasi tersebut kepada masyarakat lainnya tentang kedai Nyosoe Cak Nanang beserta produknya.

\section{SIMPULAN DAN SARAN}

Kegiatan pengabdian kepada masyarakat ini bertujuan untuk untuk memberikan pengetahuan dengan meningkatkan promosi melalui pembuatan booklet bilingual untuk kedai Nyoesoe Cak Nanang guna meningkatkan omset dan efektivitas manajemen pemasaran. Dengan demikian masyarakat khususnya pengelola kedai dapat menerapkan strategi promosi yang tepat serta memiliki alat promosi yaitu booklet yang dapat membantu kegiatan promosi. Berdasarkan hasil kegiatan, pengelola hendaknya dapat menerapkan strategi pemasaran menggunakan media cetak maupun elektronik lainnya dengan baik dan optimal.

\section{UCAPAN TERIMAKASIH}

Terima kasih disampaikan kepada Politeknik Negeri Jember melalui Pusat Penelitian dan Pengabdian Masyarakat (P3M) yang telah mendanai program ini sehingga kegiatann dapat terlaksana dengan baik.

\section{DAFTAR RUJUKAN}

Aulia, A. N., Nalawati, A. N., Asadam, A., Yuristianti, A., \& Rismawati, R. (2021). Pemberdayaan Kelompok PKK Melalui Keterampilan Olah Pangan Yoghurt Sinbiotik Untuk Mendukung Gaya Hidup Sehat dan Mendorong Perekonomian di Masa Pandemi Covid-10. Jurnal Pengabdian Masyarakat IPTEKS, 7(1), 74-82. https://doi.org/10.32528/jpmi.v7i1.5263

Ismailia, T., Dzulkifli, M., Miqawati, A. H., Bahasa, J., Pariwisata, K., \& Jember, P. N. (2019). KUNJUNGAN WISATAWAN DI POKDARWIS DAMARWULAN. 273-278.

Ismaillia, T., Miqawati, A. H., \& Wijayanti, F. (2021). ANALISIS KEBUTUHAN PENGEMBANGAN MEDIA PROMOSI DAN NYOESOE CAK NANANG REMBANGAN JEMBER PENDAHULUAN Pengabdian pada masyarakat merupakan salah satu kegiatan wajib yang harus dilakukan dalam Tri Dharma Perguruan Tinggi, selain pendidikan dan penelitian . Ke. 7(3), 278-286.

Nikmah Rahmatih, A., Yuniastuti, A., \& Susanti, R. (2018). Pengembangan Booklet. Seminar Nasional Pendidikan Biologi Dan Saintek III, 474-481.

Nugraha, B. K., Salman, L. B., \& Hernawan, E. (2016). Bakti Kusuma Nugraha*, Lia Budimulyati Salman**, Elvia Hernawan ** Universitas Padjadjaran *. Jurnal Unpad, 5.

Yunita, B., Nugraha, A. T., \& Muhib, A. (2019). Analisis Faktor-Faktor Yang Mempengaruhi Permintaan Susu Sapi Pasteurisasi Di Koperasi Produksi Susu (Kps) Bogor. Agribusiness Journal, 12(1), 52-60.

https://doi.org/10.15408/aj.v12i1.11851 